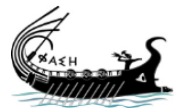

journal.phaselis.org

\title{
Phaselis Merkezi (Kent) Limanı
}

\section{The Central Harbour of Phaselis}

\author{
Erdoğan ASLAN
}

open access journals

PHASELIS: Disiplinlerarası Akdeniz Araştırmaları Dergisi'nde bulunan içeriklerin tümü kullanıcılara açık, serbestçe/ücretsiz "açık erişimli" bir dergidir. Kullanıcılar, yayıncıdan ve yazar(lar)dan izin almaksızın, dergideki makaleleri tam metin olarak okuyabilir, indirebilir, dağıtabilir, makalelerin çıktısını alabilir ve kaynak göstererek makalelere bağlantı verebilir.

PHASELIS: Disiplinlerarası Akdeniz Araştırmaları Dergisi uluslararası hakemli elektronik (online) bir dergi olup değerlendirme süreci biten makaleler derginin web sitesinde (journal.phaselis.org) yıl boyunca ilgili sayının içinde (Volume II: Ocak-Aralık 2016) yayımlanır. Aralık ayı sonunda ilgili yıla ait sayı tamamlanır.

Dergide yayımlanan eserlerin sorumluluğu yazarlarına aittir. 


\title{
Phaselis Merkezi (Kent) Limanı
}

\author{
The Central Harbour of Phaselis
}

\author{
Erdoğan ASLAN*
}

Öz: Pamphylia Körfezi'nin batı sahilinde yer alan Phaselis, üç limana sahiptir. Bu limanlardan biri olan ve kent akropolis'inin kuzeyinde yer alan Merkezi Liman alanı bu çalışmanın konusunu oluşturmaktadır. Liman alanında, limana ait mendirekler ve bu mendireklere ait sualtında çok sayıda blok bulunmaktadır. Ayrıca limanın gerisinde bir rıhtım alanı ile çok sayıda odadan oluşan atölye ve depolama alanları bulunmaktadır. Hellenistik Dönem'e tarihlendirilebilecek limanın, başlarda askeri bir liman olarak inşa edildiği ancak geç antikçağda ticari faaliyetler içinde kullanılmış olabileceği değerlendirilmektedir. Günümüzde temel seviyesinde korunmuş olan Phaselis Merkezi Liman mendirekleri için araştırılması gereken diğer bir konu ise ne zaman ve neden yıkıldıkları sorusudur. Limanın mendirekleri ve neredeyse tamamı batı yönde yıkılmış olan blokları incelendiğinde güçlü bir dalga ile tek seferde aynı yöne yıkıldıkları anlaşılmaktadır.

Anahtar Sözcükler: Phaselis · Liman · Mendirek · Sualtı · Palamar · Pamphylia

Abstract: Phaselis is located on the western coast of the Gulf of Pamphylia and has three ports. The subject of the present study is the central port located north of the city acropolis. There are breakwaters belonging to the port and numerous breakwater blocks underwater in the port. A dock, workplace and storages areas with many rooms are located behind the port. It is thought that the port, which dates back to the Hellenistic Period, was initially built as a military port, but it was subsequently also used for commercial activities in late antiquity. Another subject that should be examined concerns the breakwaters in the central port of Phaselis, these have been partially preserved, raising the question of when and why they were partially destroyed. Examination of the breakwaters of the port and their blocks, almost all of which were destroyed on the west side, suggests that they collapsed all at once in the same direction due to a strong sea wave.

Keywords: Phaselis · Harbour · Jetty · Underwater · Bollard · Pamphylia

Pamphylia Körfezi'nin batı sahilinde yer alan Phaselis, üç limana sahiptir ${ }^{1}$. Bu limanlar, Arkaik Dönem'den Geç Antikçağ’a kadar tarihlenmektedir ${ }^{2}$. Antik kaynaklarda, kentin limanları hakkında çeşitli atıflar bulunmaktadır ${ }^{3}$. Ancak bu kaynaklar içinde limanların niteliği hakkında bilgi veren Strabon'un Geographika (MÖ I. - MS I. yüzyıl) adlı eseridir. Strabon'un, "... bundan sonra, önemli, üç limanlı bir kent olan Phaselis'e ve bir göle gelinir" ${ }^{4}$ şeklindeki aktarımı dışında limanların mimarisi ya da niteliği hakkında başka bir bilgi bulunmamaktadır. Phaselis kent limanlarına

\footnotetext{
Dr., Selçuk Üniversitesi, Edebiyat Fakültesi, Arkeoloji Bölümü, Sualtı Arkeolojisi Anabilim Dalı, Konya. erdoganaslan@selcuk.edu.tr

Aslan - Baybo 2015, 1 vd.

2 Tüner-Önen 2012a, 205 vd.; Tüner Önen 2012b, 479 vd.; Aslan - Baybo 2015, 2-4.

3 Tüner-Önen 2008, 67; Aslan - Baybo 2015, 2 vd.

4 Strab. XIV. 3. 9.
} 
ilişkin modern araştırmalar incelendiğinde ${ }^{5}$ kimi araştırmaların salt limanların konumlarından söz ettiği, kimi araştırmaların ise limanların sadece in-situ korunan bazı bölümlerini ele aldığı görülmektedir ${ }^{6}$. Çalışmamız bu araştırmalardan da yararlanılarak, Phaselis Merkezi Liman alanının yeni elde edilen bulgularla ${ }^{7}$ tekrar ele alınması, daha kapsamlı bir değerlendirilme ve rekonstrüksiyon önerilerinin yapılması amacını taşımaktadır.

Üç limanı bulunan Phaselis'in çalışmamıza konu olan Merkezi (Kent) Limanı, güneyde kent akropolis'inin bulunduğu yarımada, kuzeyde kent surunun da bulunduğu kuzey demirleme alanı ile sınırlanan doğal bir koyda bulunmaktadır (Fig. 1). Girişi doğu yönünde olan liman alanı yaklaşık $7500 \mathrm{~m}^{2}$ lik bir havzaya sahiptir. Aynı zamanda kent surunun da uzantısı olan mendirekler, burasının bir kapalı liman (limen kleistos) olduğunu göstermektedir ${ }^{8}$.

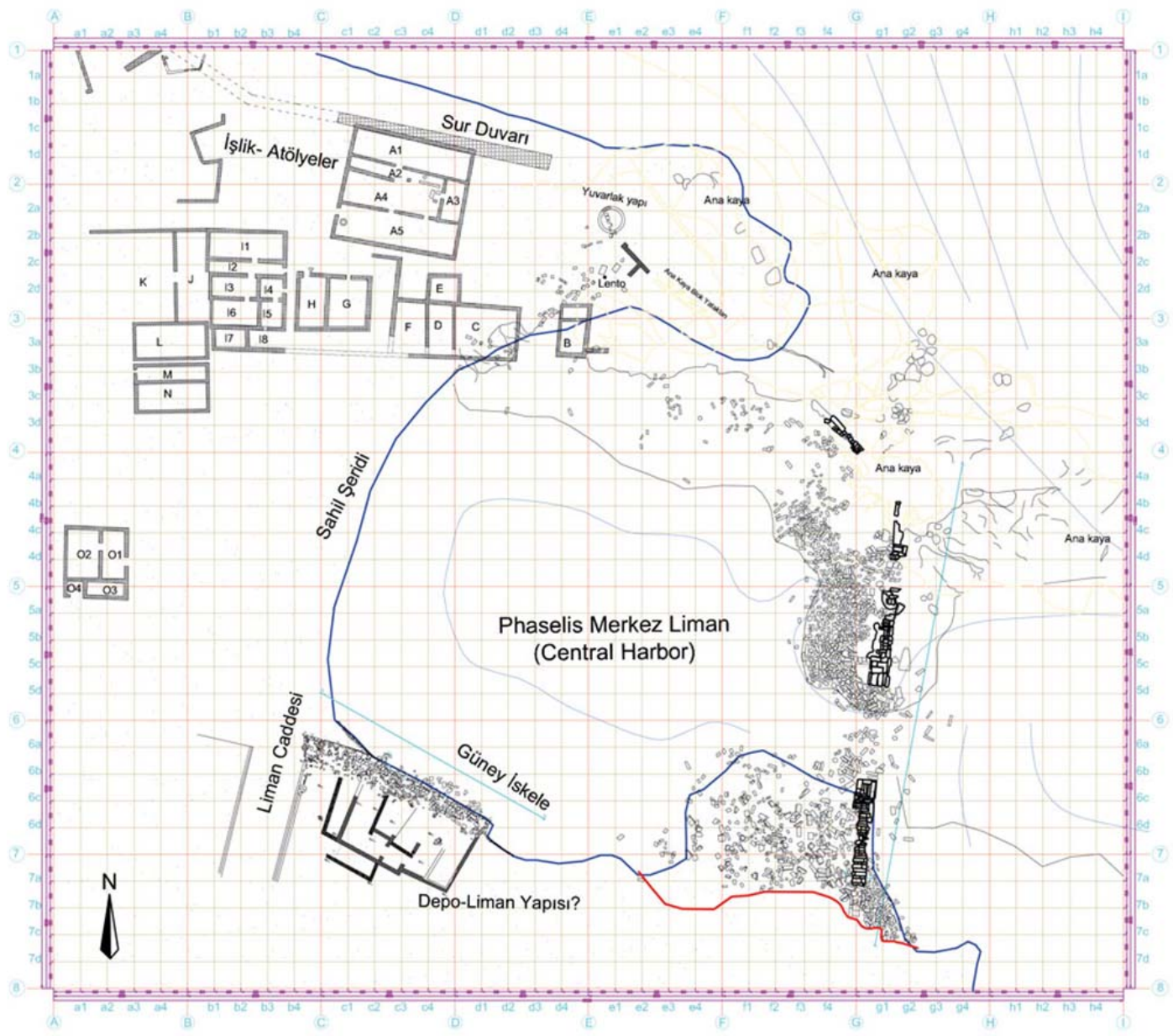

Fig. 1. Merkezi Liman Alanı Plan

Schäfer et al. 1981, 1 vd.; Arslan et al. 2013, 224; Arslan - Tüner Önen 2013, 78 vd.; Aslan - Baybo 2015, 4 vd. Beaufort 1818, 58; Lehmann-Hartleben 1923, 20, 276; Stark 1956, 172 vd.; Bean 1968, 151 vd.; Schläger Schäfer 1971, 542 vd.; Blackman 1973, 335 vd.; Schäfer et al. 1981, 13 vd.; Tüner-Önen 2008, 67-73.

72013 yılından itibaren başkanlığını Prof. Dr. Murat Arslan'ın üstlendiği Phaselis Antik Kenti ve Teritoryumu Yüzey Araştırmaları kapsamında Phaselis Limanları ve çevresine yönelik arkeolojik sualtı araştırmaları başkanlığımda yürütülmektedir.

8 Knoblauch 1969, 104-116; 1972, 50-85; Blackman 1973, 360; 1982, 371; 2008, 654. 


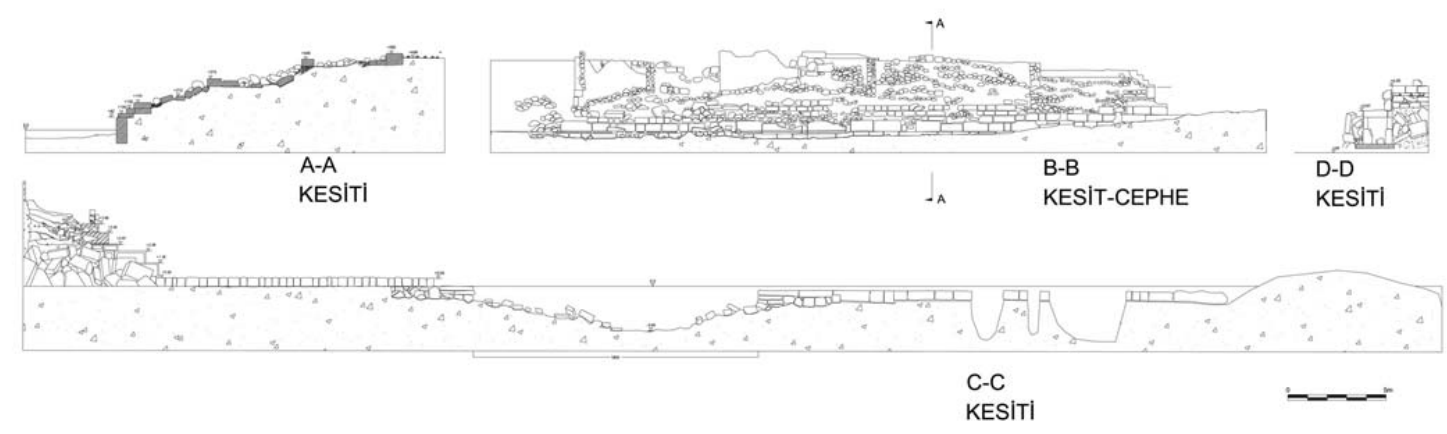

Fig. 2. Merkezi Liman Alanı Kesitleri

Kent Limanı havzası içinde liman yapılarına ve mendirek yapısına ait in-situ durumda çok sayıda blok bulunmaktadır (Fig. 1, 3). Liman, kuzey ve güneyde iki mendireğe sahiptir. Bir bölümü in-situ korunmuş mendireklerin büyük bir bölümü halen sualtında bulunmaktadır. Kuzey mendireğin güney ucu -0,15 m koddadır. Çevresinde -0,20 m ile -3,90 m arasında değişen derinliklerdeki mendireğe ait dörtgen bloklar alana dağılmıştır. Güney mendireği ise nispeten daha iyi korunmuştur ve mendireğin deniz seviyesinden itibaren $+0,55 \mathrm{~m}$ seviyesine kadar olan blokları günümüze in-situ olarak ulaşabilmiştir. Ancak her iki mendireğin de üst duvar sıralarını oluşturduğu anlaşılan blokların limanın doğusundaki açık denizden gelen dalganın etkisiyle genel itibariyle mendireğin batı kısmına doğru yıkılmıştır. Bu alanlarda yapılan belgeleme ve haritalama çalışması sonucunda alanda mendireğe ait çeşitli boyutlarda 1282 blok tespit edilmiş; ancak bu blokların alt kodunda daha birçok blok olduğu da gözlemlenmiş̧ir (Fig. 1). Liman alanındaki diğer bir mimari düzenleme ise Merkezi Liman havzasının güneybatı bölümünde, ken-

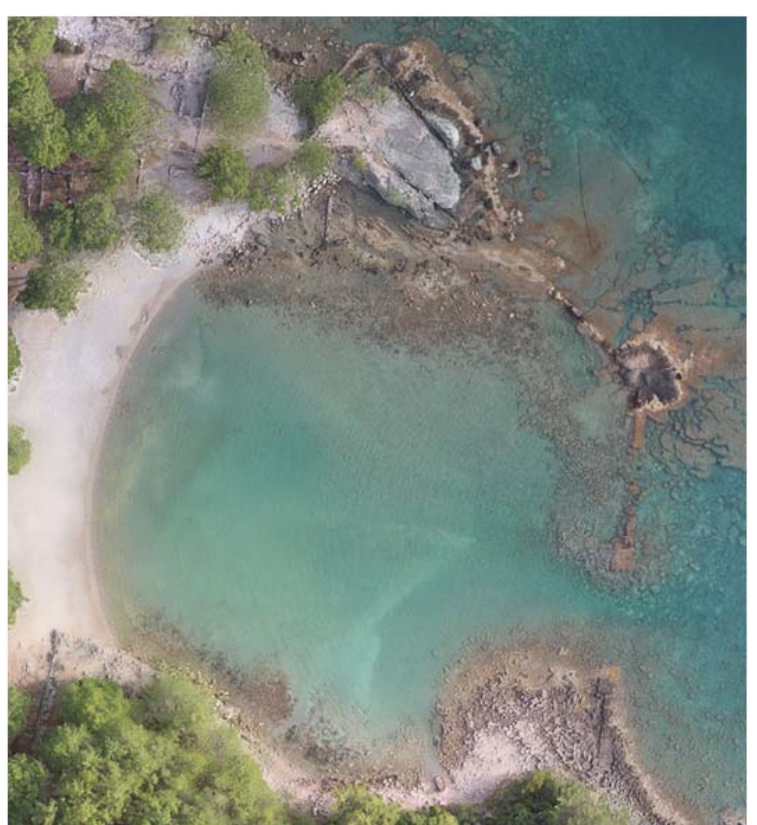

Fig. 3. Merkezi Liman Alanı Hava Fotoğrafı tin ana caddesinin kuzey ucunu dik kesen bir duvar yapısı ve gerisinde bir yapı topluluğudur. Söz konusu duvar deniz seviyesinden 1 m yüksektedir ve geriye doğru basamak yaparak kademeli olarak yükselmektedir. Bu alanda in-situ korunan palamar bağlama babaları nedeniyle bu bölümün limana yanaşan gemilerin bağlandığı bir rıhtım ve gerisindeki yapılarında rıhtıma yönelik yapılar olduğu anlaşılmaktadır. Alandaki son yapı grubunu ise Merkezi Liman havzasının kuzeybatı ve batı bölümde bulunan, duvarları temel seviyesinde korunmuş bazı yapı kalıntıları oluşturmaktadır. Bu yapı kalıntılarının limanın çevresinde konumlanmıs olmaları ve işlik ya da depolama alanı olarak kullanıımış olduklarına işaret eden bulguları ile olasıııkla limana yönelik yapılar olduğu değerlendirilmektedir. Makaleye konu olan mimari yapılar, burada dört başlık altında ele alınmıştır: I. Merkezi Liman Güney Mendireği, II. Merkezi Liman Kuzey Mendireği, III. Merkezi Liman Rıhtım Alanı ve IV. Merkezi Liman İşlik-Atölye-Depo (?) Alanları. 


\section{Merkezi Liman Güney Mendireği}

Yaklaşık 27 m uzunluğundaki Merkezi Liman Güney mendireğin deniz yönündeki uç bölümü 3,40 $\mathrm{m}$ ve ana gövdesi 2,50 m genişliğindedir. Mendirek, 0,55 m kodunda in-situ olarak korunmuştur. Mendireğin üst yapısına ait olduğu anlaşılan ve mendireğin batısında yaklaşık $1600 \mathrm{~m}^{2}$ alana dağıImış durumda 400 civarında blok bulunmaktadır. In-situ olmayan bu duvar taşlarının altında, ölçüsü alınamayan daha çok sayıda blok bulunmaktadır (Fig. 2, 4). Mendireğin korunan kısmında yaklaşık 62 blok bulunmakta ve en büyüğü yaklaşık 2,50 × 1,00 × 0,40 m ölçülerinde olan değişik boyutlu bloklarla izodomik duvar örgü tekniği kullanılarak örüldüğü anlaşılmaktadır (Fig. 5, 6). Mendireğin ana kara ile bağlandığı alanda mendireğe ait olduğu anlaşılan bir duvar sırası $4 \mathrm{~m}$ koduna kadar yine in-situ olarak korunmuştur. Bu alanda beş sıra korunan duvar örgüsü ise üst sıraya gelen blokların her sırada ölçülerinin değiştiği tespit edilebilmektedir. Ancak duvar örgüsünün bir sıra dikey bir sıra yatay olarak yerleştirildiği ve her bir blok sırası için alt sıradaki bloklar üzerine blok yatakları işlendiği görülmektedir (Fig. 6). Bu blok yataklarının amacı açık denizden gelen dalgalara mukavemet göstermesi amacıyla blokların birbirine daha organik bağ oluşturmasıdır. Mendireğin uç kısmı her hangi bir yere bağlanamadığı için denizden gelen dalgalara mukavemet gösterebilmesi amacı ile yataydaki ilk 8 sıranın kenetlerle birbirine bağlandığı görülmektedir. Bu alanda bulunan 0 ve 0,55 kodundaki in-situ bloklar üzerindeki kırlangıç kuyruğu (çift kelebek kanadı) kenet yuvalarının uzunlukları 0,32 m, en geniş uç kısımları $0,10 \mathrm{~m}$, en dar bel kısımları 0,06 m ve derinlikleri ise 0,06 metredir. Bu alanda in-situ durumda bulunan kenet yuvaları antikçağ liman mimarisinde bilinen bir uygulama olmasına karşın limanların tarihlendirilmesi noktasında ek bir veri sunmamaktadır ${ }^{9}$. Alanda bulunan blokların çoğunlukla bosajlı olduğu görülmekte ve 0,$30 ; 0,35 ; 0,40 ; 0,50 ; 0,60 ; 0.80$ m yüksekliklerde gruplanabilmektedir. Uzunluk ve genişlik açısından ise çok çeşitli olan bloklardan en büyük olanların ölçüleri yaklaşık 1,95 × 0,80 metreye ulaşmaktadır. Mendireğin ana karaya bağlandığı

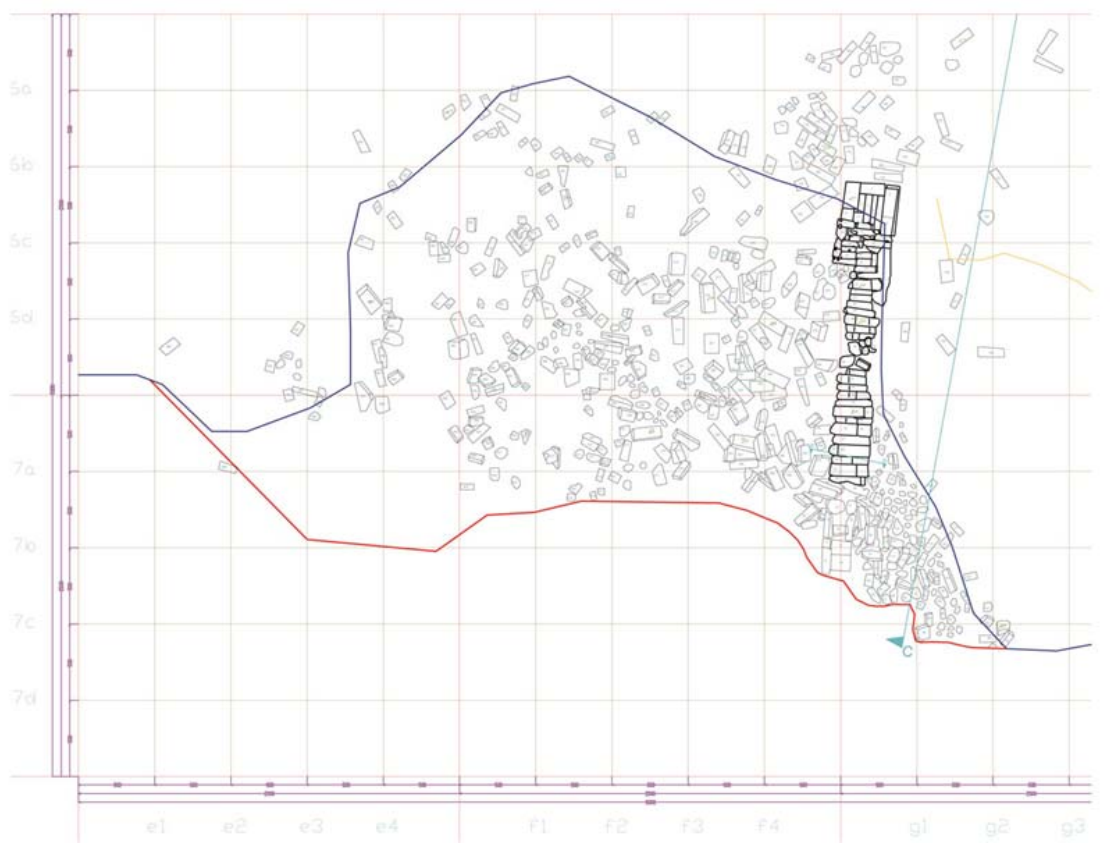

Fig. 4. Merkezi Liman Güney Mendireği Planı

Aslan 2014, 139 dn. 41. 


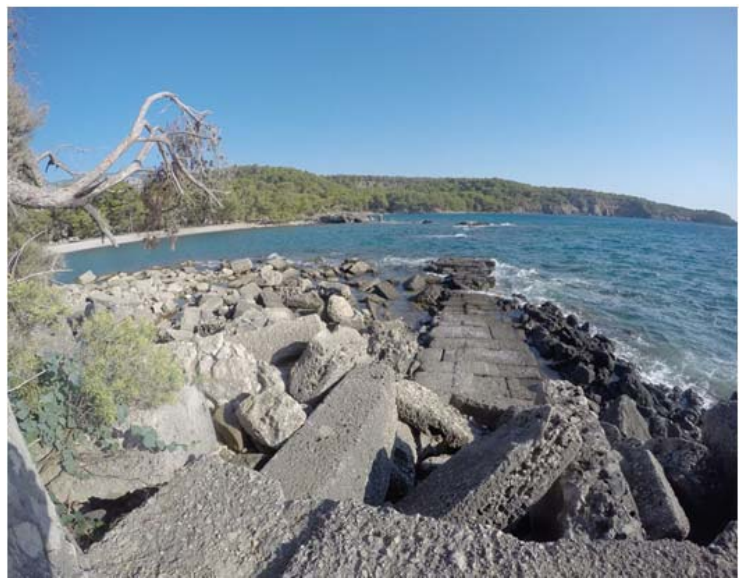

Fig. 5. Merkezi Liman Güney Mendireği Güneyden Genel Görünüm

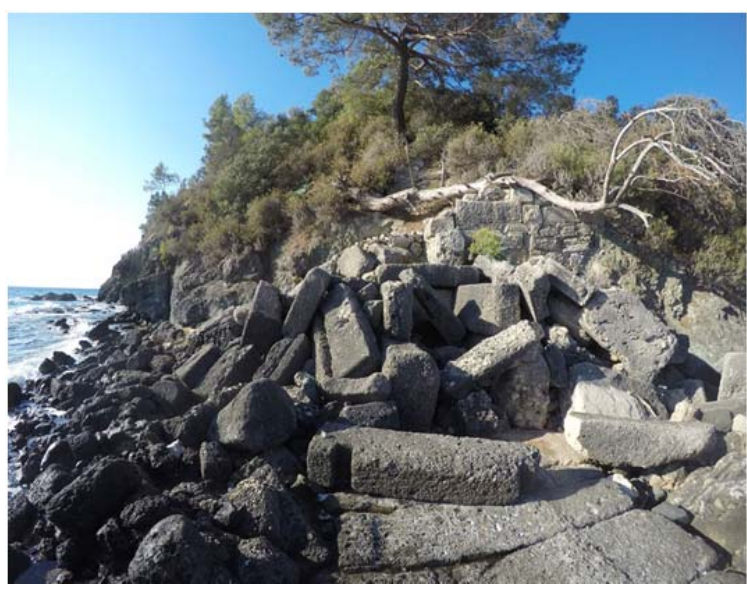

Fig. 6. Merkezi Liman Güney Mendireği In-Situ Duvar Sirası

in-situ korunan kısımda yer alan blokların deniz seviyesinden başlayarak 0,$55 ; 1 ; 00 ; 0,75 ; 0,40$; 0,85 ve 0,55 metre yükseklikteki bloklardan oluştuğu, fakat en ve boy noktasında çeşitlilik gösterdikleri görülmektedir (Fig. 2). Ancak yüksekliği 0,40 m olan bosajı blokların tamamına yakınının yaklaşık 2,45 × 0,50 $\mathrm{m}$ ölçülerinde olduğu ve bu blokların aynı duvar sırası içinde atkı niteliğinde kullanıldığı anlaşımaktadır. In-situ duvar sırasında bulunan 1,00 m yüksekliğindeki duvar sırasına ait olabilecek blokların alanda dağınık haldeki bloklar arasında tespit edilememesi bu blokların daha alt koddaki ölçülemeyen bloklar içinde kalmış olabilecekleri şeklinde yorumlanabilmektedir. Öyle ki tek seferde yıkılmış izlenimini uyandıran mendirek yapısı, bu görüşü destekler nitelikte söz konusu 1,00 m yükseklikteki duvar sırasına ait bloklar duvarının alt sıralarında yer almaktadır.

\section{Merkezi Liman Kuzey Mendireği}

Kuzey Mendireği, güney mendireğinin yaklaşık 18,00 m kuzeyinde bulunmaktadır. Kuzey - güney doğrultulu olan mendirek, liman alanının doğusunda bulunan kayalık alanında etkin kullanımı ile inşa edilmiştir (Fig. 2, 4, 7). Kuzey yönünde kesme taş blokların kullanımı ile inşa edilen mendireğin güney yönündeki uç bölümü $3,40 \mathrm{~m}$, ana gövdesi yaklaşık 2,70 $\mathrm{m}$ genişliğinde ve $-0,15$ m kodundaki in-situ olarak korunmuş kısmı ile tamamı mendirek duvarının batı kısmına dağılmış bulunan 700 civarında blok bulunmaktadır. Mendireğin korunan kısmının en üst kodunda yaklaşık 66 blok bulunmaktadır. Mendireğin en büyüğü yaklaşık 2,20 x 1,00 x 0,80 m ölçülerinde olan değişik boyutlu bloklarla izodomik duvar

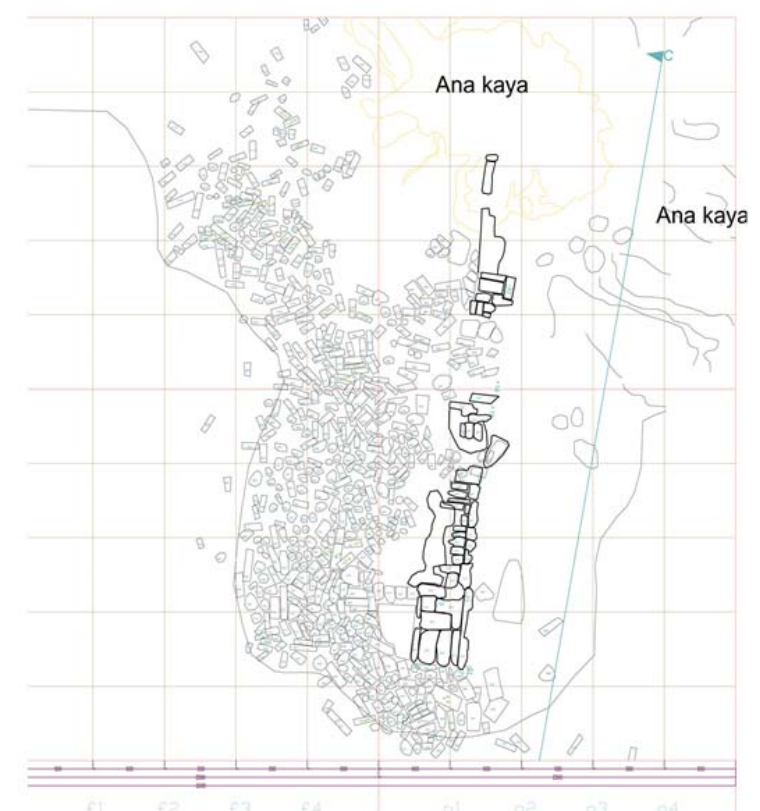

Fig. 7. Merkezi Liman Kuzey Mendireği Planı örgü tekniği kullanılarak örüldüğü anlaşımaktadır. Mendireğin gövdesi karadan 15,75 m güneydoğu yönünde uzanmaktadır. Bu noktada bulunan kayalık alanın kuzeybatı kısmıyla birleşen duvar, diğer köşesinden 34 m güneye doğru 


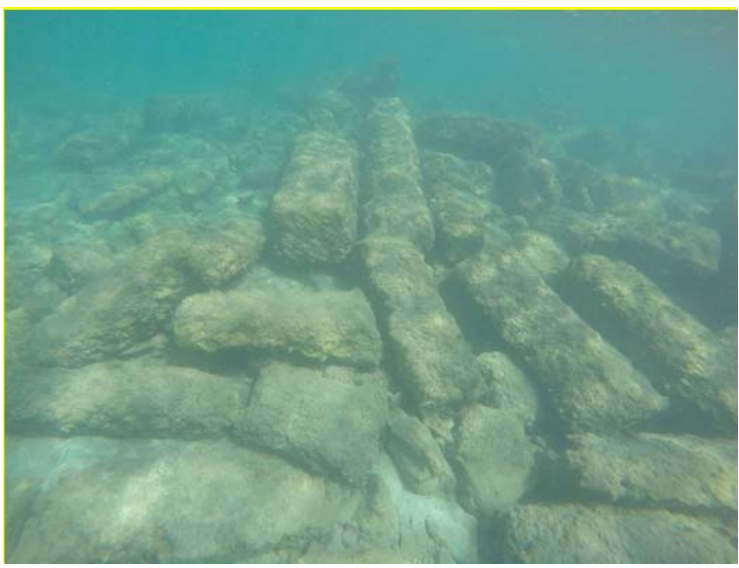

Fig. 8. Merkezi Liman Kuzey Mendireğe Ait Sualtındaki Bloklar devam etmektedir. Bir kısmı halen sualtında bulunan mendireğin güney ucu $-0,15 \mathrm{~m}$ kodda olup, çevresinde -0,20 m ile -3,90 m arasında değişen derinliklerdeki mendireğe ait yaklaşık 634 dörtgen blok yaklaşık 1500 $\mathrm{m}^{2}$ alana dağılmış halde bulunmaktadır (Fig. 7). Ölçülebilen ve planı çıkarılabilen bu blokların alt kodlarında daha çok sayıda blok bulunduğu görülmektedir. Merkezi liman güney mendireği blokları, kekamoz ve yosunla kaplıdır. Bundan dolayı blokların bosaj ya da diğer özellikleri görülememektedir (Fig. 8). Bloklar çok çeşitli boy ve yükseklik ölçülerine sahiptir; ancak genel anlamda yükseklikleri $0,30 \mathrm{~m}, 0,35 \mathrm{~m}, 0,40 \mathrm{~m}$ ve 0,60 metredir.

Limanı çevreleyen her iki mendireğin su altında kalan uç kısımları, mendireğin gövdesinden daha geniş tutularak bu alana benzer liman örneklerinde olduğu gibi ${ }^{10}$ karşılıklı kuleler inşa edildiğini düşündürmektedir.

Bu limanın kuzey mendireğinin doğusunda bir hat oluşturacak biçimde dağınık durumda çok sayıda blok yer almaktadır. Bu blokların yayılımı, mendirek duvarına paralel biçimdedir. Ancak orta bölümde mendirek duvarı ile arasında hat oluşturacak biçimde 2 metreye yakın bir boşluk olduğu gözlemlenmektedir. Bu durumu, mendireğin tek seferde ve çok güçlü bir dalga tarafından yıkıldığı ve belirli bir mesafe sürüklendiği şeklinde yorumlamak mümkündür. Diğer yandan mendireğin batı bölümünde, mendireğe ait yıkılmış durumda bulunan çok sayıdaki bloğun aralarından, daha alt seviyesinde mendireğin ana duvarının iç kısmında rıhtım ya da benzeri bir düzenleme olabileceğine işaret eden düzenli bazı blok sıraları da görülmektedir. Bu blokların niteliği ve devamı olup olmadığı üst kodlardaki diğer bloklar nedeniyle tespit edilememektedir.

Merkezi limanın kuzey mendireği, kuzeydoğu yönüne dönerek kayalık küçük bir burun ile birleşmektedir. Bu alandaki mendirek duvarı günümüze ulaşamamıştır. Ancak kayalık yarım adanın üzerinde mendireğin doğrultusunda ana kayaya işlenmiş blok yatakları halen izlenmektedir. Söz konusu kayalık yarımadanın üzerinde bazı geç dönem duvar düzenlemeleri ile dört bloğu in-situ korunmuş deniz seviyesinden $+4,20$ m kodunda yuvarlak bir yapı temeli bulunmaktadır (Fig. 1, 9). Korunan bölümün uzunluğu $1,60 \mathrm{~m}$ eni ise 0,55 metredir ve konumu itibariyle bir gözetleme kulesi ya da deniz feneri niteliğinde bir yapıya sahiptir. Söz konusu alanda zeminde çok miktarda murex kabuğu da bulunmakta-

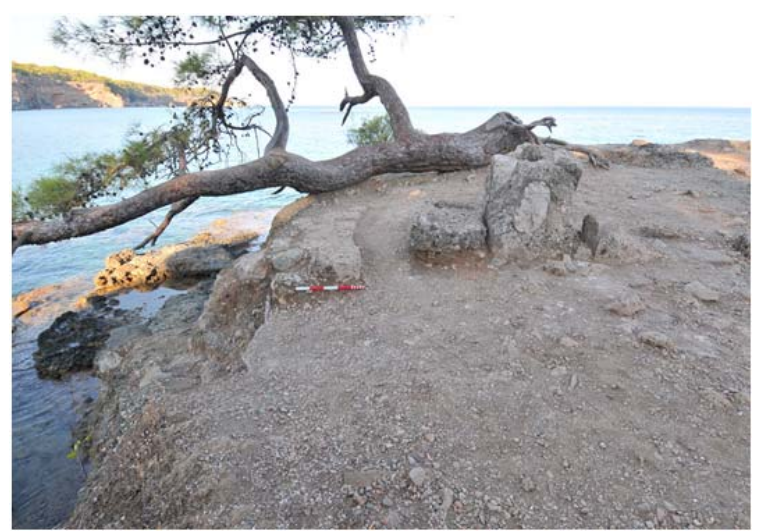

Fig. 9. Merkezi Liman Kuzey Mendireği Yuvarlak Yapı Batıdan Görünüş

10 Knoblauch 1969, 104-116; 1972, 50-85; Blackman 1973, 360; 1982, 371; 2008, 654; Bjorn 2011, 15 vd. 
dır. Dolayısıyla bu alanda yer alan yapıların işlik olması da gündeme gelmektedir. Alanın kazısı yapılmadan, duvarların niteliği ve birbirleri ile bağlantısı açığa çıkarılmadan bu alandaki yuvarlak yapının işlevi bu aşamada bilinememektedir. Ancak bu alanda diğer bloklarla boyut ve şekil yönünden benzeşmeyen iki adet büyük boyutlu blok bulunmaktadır. Bloklardan biri 1,44 x 0,94 $x$ $0,85 \mathrm{~m}$, diğeri ise $1,67 \times 1,10 \times 0,81 \mathrm{~m}$ ölçülerindedir ve her ikisinde de lento benzeri bir profil ile menteşe zıvanalar bulunmaktadır. Bu durum güçlendirilmiş bir kapıya ait lento blokları olabileceğini düşündürmektedir. Öyle ki bu alanda yer alan yuvarlak (fener ya da gözetleme kulesi?) yapıya ait bir giriş ya da kent surunun bu bölümünden dışarı açılan bir kapı bulunma olasılığını güçlendiren nitelikte bir bulgudur.

\section{Merkezi Liman Rıhtım Alanı}

Merkezi Liman havzasının güneybatı bölümünde bulunmaktadır. Rıhtım bir duvar yapısı ve gerisindeki yapı topluluğundan oluşmaktadır (Fig. 1, 2, 11). Söz konusu duvar deniz seviyesinden $1 \mathrm{~m}$ yüksektedir ve geriye doğru basamak yaparak kademeli olarak yükselmektedir (Fig. 10). Merkezi limanın güneybatısında yer alan rıhtım duvarı konglomera bloklardan oluşmaktadır. Günümüze ulaşmıs durumu ile duvarın ölçüleri 39 × 4,5 metredir. Kullanılan bloklar, yaklaşık 1,50 ila 2 m uzunluğunda ve 0,30 ila $0,60 \mathrm{~m}$ genişliğindedir. Duvarın güneydoğu cephesi, 0,70 1,00 m yüksekliktedir. Bu duvar, kuzeybatıda 2,80 metreye kadar korunmuştur. Duvarı oluşturan blokların arası, irili ufaklı moloz taşlar ve harç ile doldurularak desteklenmiştir. Limanın güneybatı kısmında $+2,00$ metreden başlayarak 4,50 m yüksekliğe ulaşan farklı ölçülerde, iç içe geçmiş odaların oluşturduğu mekânlar bulunmaktadır. Bu mekânlara ait duvarların kalınlığı 0,70 metredir ve kapladığı alansa yaklaşık $27,5 \times 15,5$ metredir.

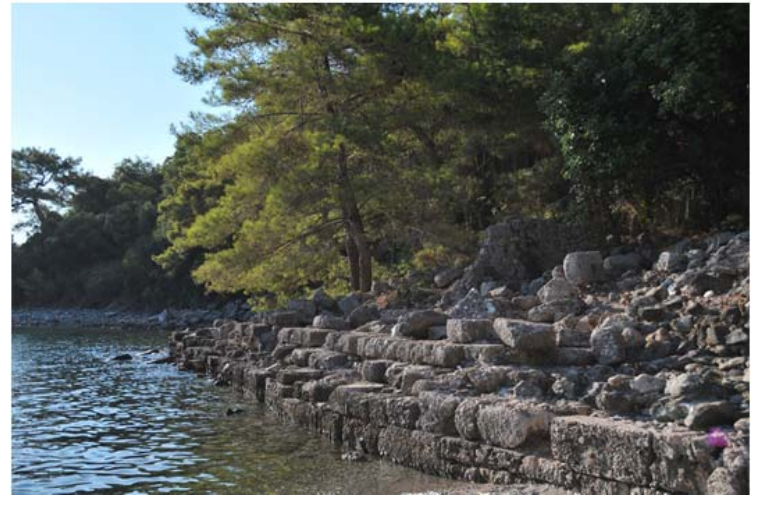

Fig. 10. Merkezi Liman Rıhtım Alanı Batıdan Görünüş

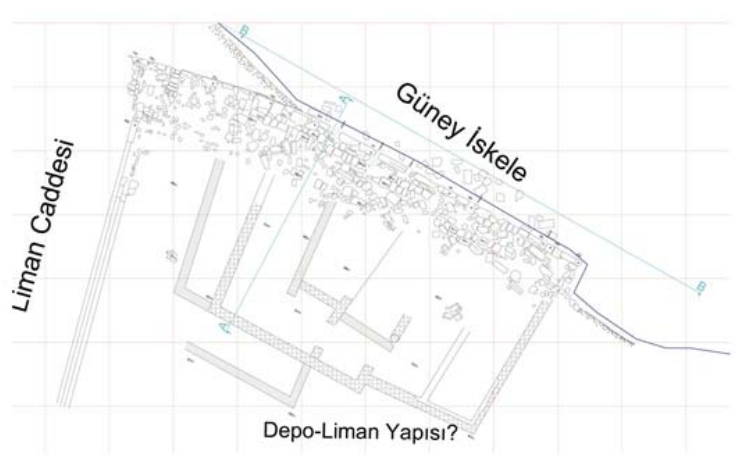

Fig. 11. Merkezi Liman Rıhtım Alanı Planı

Doğu-batı doğrultulu duvar üzerinde in-situ olarak korunmuş, 1 tanesi sağlam durumda toplam 6 adet palamar bağlama babası bulunduğu anlaşılmaktadır. Bazıları birbirine 3 metre bazıları ise 6 metre aralıklarla dizilmiş olan in-situ durumdaki mantar biçimli (bollard) bağlama babalarının ölçüleri 0,60 × 0,40 × 2 metredir ve benzerlerinden farklı olarak denize doğru yatay olarak durması ünik bir özelliktir ${ }^{11}$ (Fig. 12). Antikçağ limanlarında mantar biçimli bağlama babaları

11 Genel terminolojide Moorig Stone (halka biçimli bağlama yeri) ve Bollard (İskele babası biçiminde bağlama yeri) denen ve gemilerin rıhtım ya da iskeleye yanaştıktan sonra halatlarını bağladıkları taş ya da metal düzenlemelerden halka ya da delik biçiminde olanlara "palamar bağlama halkası", monolit biçimde mantar ya da sütun şeklinde olanlaraysa "palamar bağlama babası" denilmektedir. Bk. Testaguzza 1964, 173; 


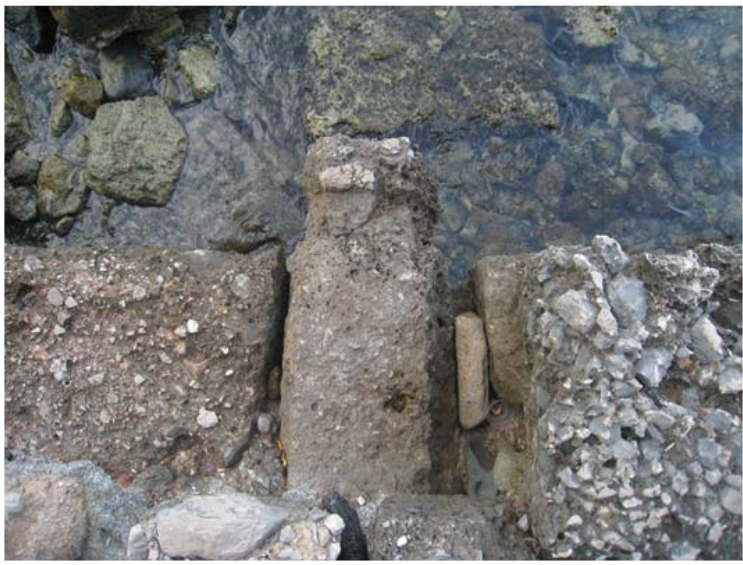

Fig. 12. Merkezi Liman Rıhtım Alanı Palamar Bağlama Babası (Bollard)

görülmekle beraber bunlar dikey konumlandırılmaktadırlar, böylesine yatay konumlandırılan bloklara daha çok bağlama halkası (mooring stone) yapılmaktadır ${ }^{12}$. Her iki palamar bağlama tipinin özelliklerini birlikte taşıması dikkat çekici bir özelliktir. Bunun nedeni büyük olasılıkla rıhtım üzerindeki kısıtlı alanı daraltmamak adına, rıhtım duvarına yatay olarak konumlandırıldığı anlaşılan blokta bağlama halkası olması beklenirken, bloğun cinsinin konglomera olması nedeniyle ortasına açılacak halka bloğu zayıflatacağından halka yerine bollard adı verilen mantar biçimli olarak yapılması kaçınılmaz hale gelmiştir. Bağlama babalarının bulunduğu duvar yapısı yaklaşık $40 \mathrm{~m}$ uzunluğundadır ve bu alanın gemilerin bağlandığı rıhtım ve gerisindeki yapıların da rıhtımla ilişkili yapılar olduğunu göstermektedir. Rıhtım duvarının batı bölümünde $0,40 \times 0,60 \mathrm{~m}$ ölçülerinde bir kanal görülmektedir.

Kanalın daha önceki yıllarda C. Bayburtluoğlu tarafından yapılan kazılar sırasında Sütunlu Cadde üzerinde bulunan Latrina yapısının kanalizasyon tesisi olarak inşa edilen ve liman içine doğru tahliye edilen atık su kanalının ağzı olduğu anlaşılmaktadır ${ }^{13}$. Rıhtım işlevi gören bu alanın duvar işçiliği, duvar örgü tekniği ve kullanılan malzemesi limanın mendireklerinden oldukça farklıık göstermekte ve limanın ilk inşa tarihinden daha geç bir dönemde yapıldığına işaret etmektedir. Öyle ki liman mendireklerinde kullanılan bloklar bosajlı ve büyük boyutlu bloklar olmasının yanı sıra rıhtım alanında olduğu gibi bağlayıcı malzeme olarak harç kullanılmamıştır. Dolayısıyla söz konusu rıhtım ve gerisinde depo ya da dükkân benzeri mimari yapılar limanın ilk inşasından daha geç bir tarihte limanın tekrar organize edilmesi ile rıhtıma yanaşan gemilerin kargolarını boşalttıkları ve Phaselis'ten ihraç edilecek malların gemilere yüklendiği işlevsel bir ticaret alanı olduğunu göstermektedir. Benzer ticari amaçlı limanlarda da bu alanda dükkânlar, depolar, gümrük binaları ve sarnıçlar gibi mimari yapılar bulunmaktadır ${ }^{14}$. Ancak askeri amaçlı limanlarda bu olgu ile karşılaşılmamakta ve askeri liman özellikleri gösteren Phaselis Merkezi Liman alanında da sözü edilen bu yapılar ile aşağıda detaylarına yer verdiğimiz diğer depo-işlik ve atölyeler limanın ilk inşasındaki amaca yönelik olarak bulunmaması gereken yapılardır.

\section{Merkezi Liman İşlik-Atölye-Depo? Alanları}

Merkezi Liman havzasının kuzeybatı ve batı bölümde temel seviyesinde bazı yapı kalıntıları görülmektedir. Bu yapı kalıntılarının limanın çevresinde konumlanmış olmaları ve işlik ya da depolama alanı olarak kullanılmış olduklarına işaret eden bulguları ile olasılıkla limana yönelik yapılar olduğu değerlendirilmekte ancak işlevleri kazı yapılmadan tam olarak anlaşılamamakta-

Blackman 1973, 355; 1982, 203; Williams 1976, 73; Theodoulou-Memos 2007, 253.

12 Mengarelli 1900, 637-638 fig. 2; Gerkan 1959, 142 fig. 1; Testaguzza 1970, 171; Shaw 1972 fig. 21; Blackman 1982 fig. 2; Casson 2002, 121; Hadjidaki - Stefanakis 2004, 118; Teodoulou - Memos 2007, 257 fig. 4; Doksanaltı - Aslan 2013, 234 fig.7; Aslan 2011, 48 lev. 26. 2.

13 Bayburtluoğlu 1983, 183 vd.

14 Shaw 1972, 91; Blackman 1982, 204; 2008, 653; Casson 2002, 143. 
dır. Alanda kimi tek odadan oluşan kimi ise birden çok odadan oluşan 3 kompleks ve bu komplekslere ait odalar dahil toplamda 28 oda tespit edilebilmektedir (Fig. 1, 13). Bu odalardan bazıları da kendi komplekslerini oluşturacak biçimde konumlandırılmış ancak odalar arası geçiş ve bağlantı yerleri yoğun dolgu nedeniyle tespit edilemediği için şimdilik bağımsız odalar olarak tanımlanmıştır. Ayrıca alanda daha fazla yapı olduğuna ilişkin bazı duvar ve blok kalıntıları da bulunmaktadır ancak günümüzde alanın üzerinde dolgu toprağı olması nedeniyle diğer yapıların planları bu aşamada tespit edilememektedir. Alanda tespit edilen ve plana işlenen yapılar alfabetik sıra ile adlandırımış birden çok odadan oluşan kompleksler detaylı olarak tanımlanmış tek odadan oluşan mekânların ise sadece konumu ile ölçüleri verilmiştir.

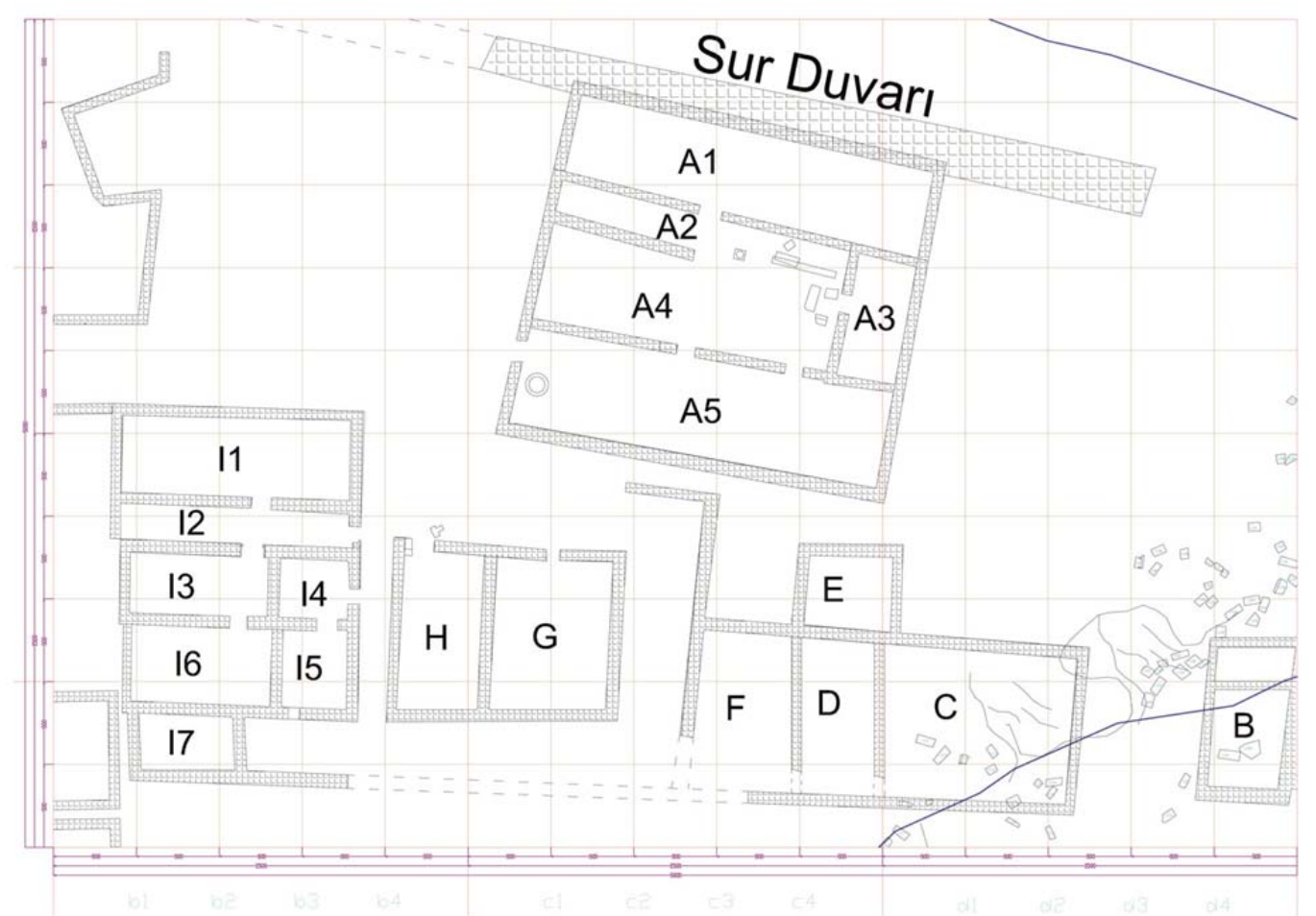

Fig. 13. Merkezi Liman Işlik-Atölye-Depo? Alanları Plan

\section{A Yapı Kompleksi}

Merkezi limanın kuzeyinde yer alan ve aynı zamanda kuzey demirleme alanının güney sınırını da oluşturan kent suruna yaslanmış olarak konumlandırılmıştır (Fig. 13). Yaklaşık $23 \times 20 \mathrm{~m}$ ölçülerindeki yapı beş odadan oluşan bir yapı kompleksidir ve duvarları ikinci kullanımı olduğu anlaşılan devşirme bloklar, moloz taşlar ve harç kullanılarak genişliği 0,55 m ile 0,70 m arasında değişen ölçülerdedir. Duvarlarından bazıları temel seviyesinde korunmuşken bazı duvarları ise 4 $m$ seviyesine kadar korunmuştur (Fig. 14). Yapının odaları kuzeyden güneye doğru A1, A2, A3, A4, A5 olarak isimlendirilmiştir. Yapıya batı yönünden 22 × 5,70 m ölçülerindeki A5 adı verilen dikdörtgen odadan girilmektedir. Odanın güneybatı köşesinde, köşeden 1,40 m kuzey yönünde, dış çapı $3 \mathrm{~m}$ iç çapı $1,40 \mathrm{~m}$ olan dış yüzünde iri moloz taşlar, iç yüzünde daha küçük moloz taşlarla örülmüş ocak benzeri yuvarlak bir düzenleme bulunmaktadır (Fig. 15). A5 odasının kuzey duvarında $1 \mathrm{~m}$ genişliğinde iki adet kapı açıklığı bulunmakta ve bu kapılardan A4 adı verilen odaya geçilmektedir. A4 odası yaklaşık 18 × 5,80 m ölçülerindedir ve doğu duvarı ile kuzey duvar- 


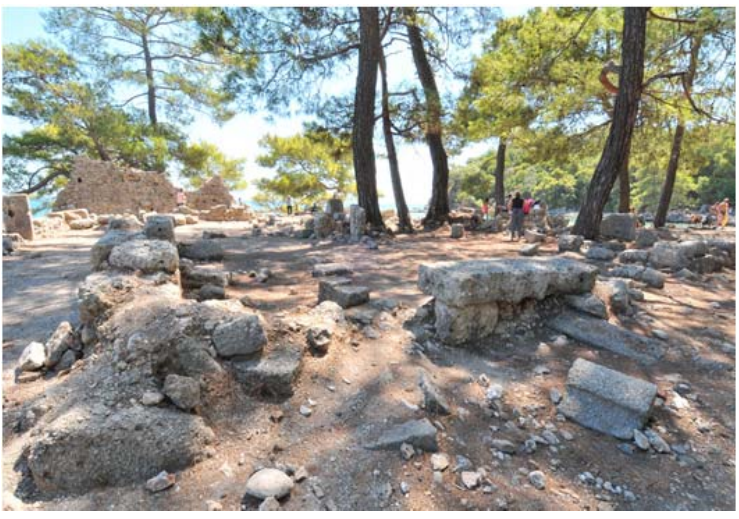

Fig. 14. Merkezi Liman A Yapı Kompleksi Batıdan Görünüş

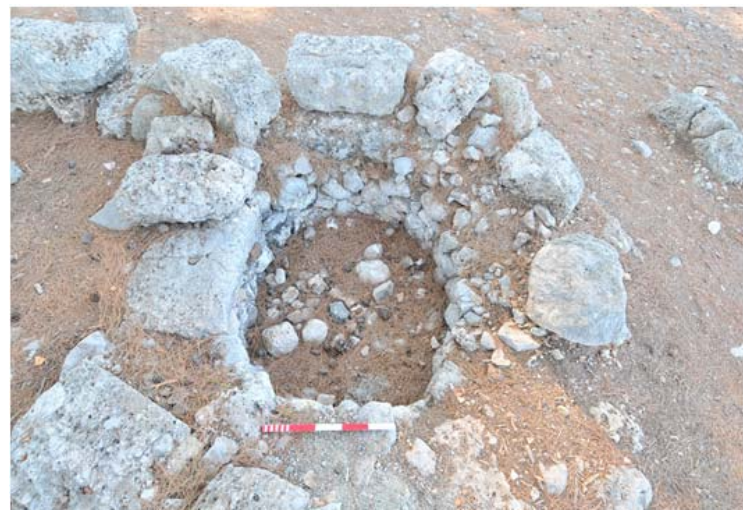

Fig. 15. A Yapı Kompleksi A5 Odası Ocak

ında bulunan 1,10 m genişliğindeki kapılar ile A2 ve A3 odalarına geçilen kapı açıklıkları bulunmaktadır. A4 odasının doğu duvarında bulunan kapı açıklığından girilen A3 odası 7,40 × 3,50 m ölçülerindedir ve sadece A4 yapısı ile kapı bağlantısı bulunmaktadır. Kapıya ait söve ve lento parçaları bu açıklığın iki yanında düşmüş olarak görülmektedir. A3 odasının 3,50 m seviyesine kadar korunmuş olan doğu duvarında ahşap hatıl deliklerinin bulunması yapının en azından bu bölümünün iki katlı olabileceğini göstermektedir. A4 odasının kuzey duvarındaki kapı açıklığından ise A2 oda-koridoruna geçilmektedir. A2 oda-koridoru yaklaşık $18 \times 2$ m ölçülerindedir ve mekanın orta bölümünde kuyu bileziği günümüze ulaşmış bir sarnıç bulunmaktadır (Fig. 16). Buradaki sarnıcın hacmi ve gövde biçimi içinin moloz ile dolmuş olması nedeniyle anlaşılamamaktadır. A2 odasının kuzey duvarında bulunan 1 m genişliğindeki kapı açıklığından A1 odasına geçilmektedir ve dikdörtgen odanın ölçüleri içten içe $22 \times 5$ metredir. A yapısının odaları dikdörtgendir ve A3 odası dışındaki odalar doğu-batı uzantııdır. Odalar arası geçişi sağlayan kapı

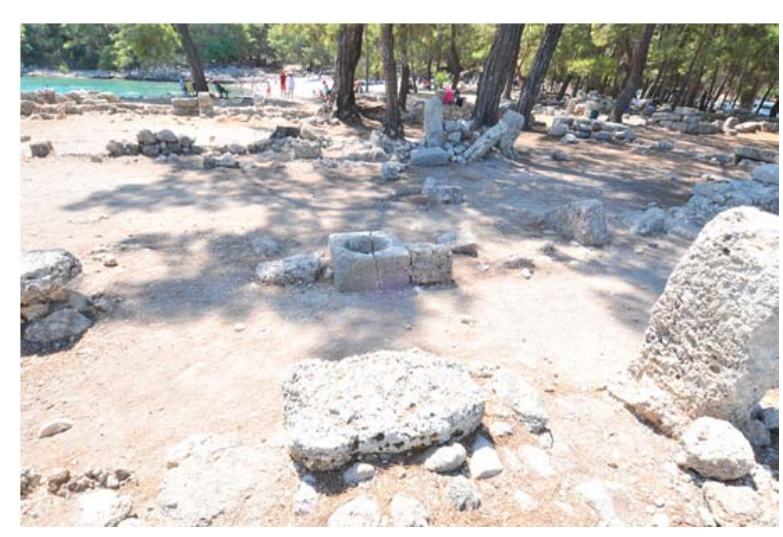

Fig. 16. A Yapı Kompleksi A2 Odası Sarnıç açıklıklarının daima uzun duvarların orta bölümlerinde bulunması dikkat çekici bir düzenleme olarak karşımıza çıkmaktadır. Diğer yandan A yapısının konumu, girişindeki ocak?, A2 odasındaki sarnıç ve birbirine paralel sıralanmış granarium benzeri uzun dikdörtgen odaları ile depolama alanı da bulunan bir üretim atölyesi görünümündedir. $\mathrm{A} 3$ odasında yer alan ve ikinci kata ilişkin hatıl delikleri ise yapının alt katında üretim ve depolamanın, üst katında ise yaşam alanlarının bulunma ihtimalini düşündürmektedir.

\section{Yapı Kompleksi}

I yapı kompleksi adı verilen yapı A yapısının yaklaşık 8 m güneybatısında yer almaktadır (Fig. 17). Sekiz odadan oluşan yapı dıştan dışa yaklaşık 23 × 15 m ölçülerindedir ve duvarları A yapısındakine benzer nitelikte ikinci kullanımı olduğu anlaşılan devşirme bloklar, moloz taşlar ve harç kullanılarak genişliği $0.60 \mathrm{~m}$ ile $0.80 \mathrm{~m}$ arasında değişen ölçülerdedir. Duvar, temelden 1.30 m seviyesine kadar korunmuştur. Yapı sekiz mekândan oluşmakta ve doğu cephesinde söveleri korunmuş olan iki giriş açıklığı bulunmaktadır. Giriş kapısının biri 11, 12, 13, 16 mekânlarına diğeri 
ise 14, 15 mekânlarına erişimi sağlamaktadır (Fig. 13). Yapının güneyinde bulunan 17 ve 18 odalarının giriş açıkıkları tespit edilememiştir ancak bu alana olasılıkla günümüze ulaşmayı başaramamış olan 18 odasının doğu duvarından giriş sağlanıyor olmalıdır. Yapının 1,00 m genişliğindeki doğuya bakan ilk girişinden 12 adı verilen $13,70 \times 2,05$ m ölçülerindeki koridor benzeri ince uzun bir mekâna ulaşılmaktadır. Doğu-batı uzantıı bu alanın kuzey ve güney duvarlarının orta kısmına yakın bölümlerinde 1,20 m genişliğinde iki kapı açıklığı bulunmaktadır. Kuzey

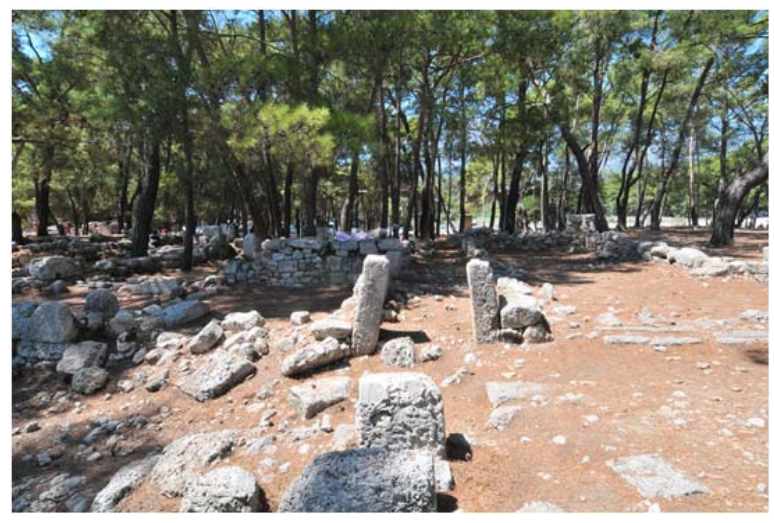

Fig. 17. Merkezi Liman I Yapı Kompleksi Doğudan Görünüş duvarındaki kapıdan 11 odasına, güney duvarında yer alan kapı açıkığından ise 13 odasına geçiş sağlanmaktadır. Yapının en kuzeyindeki odası olan 11 odası 13,70 × 4,75 m ölçülerinde doğu-batı uzantılı dikdörtgen bir plan göstermektedir ve duvarları yer yer temel seviyesinden 1,00 m seviyesine kadar korunmuştur. 12 koridorunun güney duvarında bulunan 1,20 m genişliğindeki kapı açıkığından 13 odasına geçiş sağlanmakta ve 13 odası 8,35 × 3,65 m ölçülerindedir. Duvarları yaklaşık 1,00 m seviyesine kadar korunmuş olan odanın güney duvarında 12 koridorundan 13 odasına geçilen kapı açıkığııın karşı hizasında, 13 odasının güney duvarında bulunan 1,00 m genişliğindeki kapı açıklığından ise 16 odasına geçiş sağlanmaktadır. 16 odası 8,50 x 3,20 m ölçülerindedir ve duvarları 1,20 m seviyesine kadar korunmuştur. I yapı kompleksinin doğu cephesinde bulunan ikinci kapı açıklığından ise 14 odasına ve bu odadan da 15 odasına geçiş sağlanmaktadır. 14 odası 4,20 × 3,50 m ölçülerindedir ve bu odanın güney duvarında bulunan 1,20 m genişliğindeki kapı açıklığından 4,00 $x$ 4,60 m ölçülerindeki 15 odasına geçilmektedir. 14 ve 15 odaları her ne kadar ana yapı ile beraber planlanmış olsa da girişleri itibariyle ana yapıdan soyutlanmışlardır. Buna benzer özellikte yapının güneyinde bulunan 17 ve 18 odalarına da ana yapıdan giriş bulunmamakta olasıııkla doğu cephede üçüncü bir giriş ile 18 odasına girilmekteydi. 18 odasının doğu duvarı günümüze ulaşamamıştır ancak korunan bölümünün ölçüsü yaklaşık 7,00 × 3,20 metredir. 18 odasının batısında 5,50 × 3,20 m ölçülerinde ve I yapısının güneybatı köşesinde 17 odası bulunmaktadır. Bu yapının girişi duvarlarının yıkı Imış olması ve dolgu nedeniyle tespit edilememektedir ancak olasılıkla 18 odasından giriş sağlanıyor olmalıdır. I yapısının neredeyse temel seviyesinde korunmuş olan duvarları ve odalarının zeminindeki yoğun dolgu nedeniyle işlevi tam anlaşılamamaktadır. Ancak I yapısının A yapısına benzer nitelikte doğu-batı yönlü dikdörtgen ve birbirine paralel odalar içermesi, kapı girişlerinin büyük oranda uzun yüzlerdeki duvarların orta bölümüne yakın olmaları ve benzer duvar işçilikleri içermesi hem çağdaş oldukları hem de benzer işlevde olduklarını düşündürmektedir.

\section{o Yapı Kompleksi}

Merkezi liman havzasının yaklaşık 40 metre batısında yer alan yapı kompleksi duvarları, 1,00 m seviyeye kadar korunmuş ve 4 odadan oluşmaktadır (Fig. 1). O yapısı dıştan dışa 13,50 x 12,00 m ölçülerindedir ve alandaki diğer çok odalı yapılara oranla daha küçük bir yapıdadır. Yapının girişi doğu yönde 1,50 m genişliğinde ve uzun yüzün ortasındadır. Doğu yöndeki giriş açıklığından 8,90 x 4,10 m ölçülerindeki O1 odasına ulaşılmaktadır. Kuzey-güney uzantılı ve dikdörtgen planlı O1 odasının batı uzun duvarı ortasında 1,40 m genişliğindeki bir kapı açıklığı ile 01 odasının batısında 


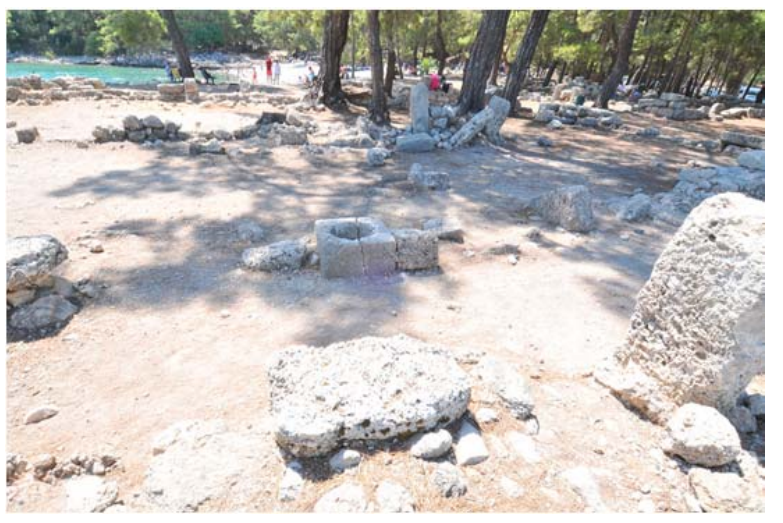

Fig. 18. Merkezi Liman B Odası Kuzeyden Görünüş

yer alan $\mathrm{O} 2$ odasına geçilmektedir. $\mathrm{O} 2$ odası 8,90 × 6,00 m. ölçülerinde dikdörtgen bir plandadır ve 01 odası ile aynı doğrultudadır. O yapısının diğer iki odası olan $\mathrm{O} 3$ ve $\mathrm{O} 4$ odaları yapının güney bölümünde yer almaktadır ancak $\mathrm{O} 1$ ve $\mathrm{O} 2$ odaları ile bir kapı bağlantısı bulunmamaktadır. Girişinin ayrıca verildiği anlaşılan, ancak kapı açıklığı tespit edilemeyen 03 odası 6,85 × 2,45 m ölçülerindedir. Yapının son odası olan $\mathrm{O} 4$ odası ise kareye yakın planlıdır ve 2,90 × 2,50 m ölçülerindedir. Odanın girişinin güneyden verildiği anlaşılmakta, ancak kapı açıklığının kar-

şılığı olan duvar yıkılmış olduğu için açıklığın ölçüsü alınamamaktadır.

\section{$B, C, D, E, F, G, H, J, K, L, M, N$ Odaları}

Tek odadan oluşan ya da temel seviyesinde dahi izleri ve diğer mekânlarla bağlantısı olup olmadığı tam olarak takip edilemeyen yapılardan (Fig. 1, 13) ilki merkezi liman alanının kuzey kıyısındaki liman havzası kenarında yer almaktadır. B yapısı adı verilen ve 9,80 ×6,00 m ölçülerindeki yapının duvarları temel seviyesinde izlenebilmektedir. Yapı iki bölmeden oluşmakta ve yapının ilk bölümü 6,00 × 4,60 m, ikinci bölümü 2,00 × 4,60 m ölçülerindedir. Yapının güney bölümü halen sualtında bulunmakta ve kuzey bölümü eğimli ana kaya yamacına oturtulmuş olması nedeniyle deniz seviyesinin 0,40 m üst kodundadır (Fig. 18). B yapısının 10 metre batısından başlayarak I yapı kompleksine doğru bir hat halinde doğu-batı yönünde sıralanmış $C$, D, E, F, G ve H adı verilen tek odalı yapılar bulunmaktadır (Fig. 1). Yukarıda yapı kompleksi olarak detaylıca tanımlanan I yapısının batısında $K$ ve J odaları, I yapısının güneydoğusunda ise $L, M, N$ odaları tek odalı mekânlardır (Fig. 13). Bunların dışında alanda temel seviyesinde bazı duvarlar da tespit edilebilmekte, ancak bu duvarların nasıl bir mekân oluşturduğu ya da diğer yapılarla bağlantısı dolgu nedeniyle anlaşılamamaktadır. Liman havzasının kuzeybatı bölümünde B yapısının batısında konumlanan yapılardan ilki $C$ odasıdır. Bu odanın ölçüleri yaklaşık 11,00 x 9,10 metredir ve kuzey bölümünde günümüz yürüme zemini seviyesinde korunmuş olan temel izlerinin aksine güney bölümündeki duvar temelleri güçlükle seçilebilmektedir. C odası ile benzer nitelikte temel duvarları güçlükle seçilebilen $D, E$ ve $F$ odalarının ölçüleri ise $D: 9,30 \times 4,40$; E: 4,30 × 5,15; F: $9,50 \times 5,70$ metredir. C, D, E ve $F$ odalarının giriş açıklıkları ve birbirleri ile bağlantısı olup olmadığı anlaşılamamaktadır. Ancak odaların bir arada belirli bir dizin içinde olmaları ve birbiriyle ortak duvarları kullanmaları bu odaların bir yapı kompleksinin bölümleri olduğuna işaret etmektedir. Bu odaların batısında yer alan ve nispeten daha iyi korunmuş $\mathrm{G}$ ve $\mathrm{H}$ odaları bulunmaktadır. 8,70 × 7,10 m ölçülerindeki G odasının duvarları yer yer $1 \mathrm{~m}$. seviyesine kadar korunmuştur ve odanın kuzey duvarı ortasında 0,90 m genişliğinde bir kapı açıklığı bulunmaktadır. G odasının batısında, H odası yer almaktadır. Her iki oda, ortak duvara sahiptir. H odası 8,70 x 4,65 m ölçülerindedir ve $G$ yapısında olduğu gibi 1,00 m genişliğindeki girişi kuzey yöndedir. $\mathrm{G}$ ve $\mathrm{H}$ odalarının birlikte planlanarak inşa edildiği anlaşılmakta, ancak işlevlerine yönelik bir bulgu elde edilememektedir. I yapı kompleksinin batısında J odası ve bu odaya girişi sağlayan kapının açıldığı K odası bulunmaktadır (Fig. 1). J odası 16,80 x 5,70 m ölçülerinde kuzeygüney doğrultulu dikdörtgen bir yapıya sahiptir. Duvarları yaklaşık 1,00 m seviyesine kadar korunmuş olan yapının batıya bakan uzun duvarının orta bölümünde $\mathrm{K}$ odasına açılan 1,90 m 
genişliğinde bir kapı açıklığı bulunmaktadır. $\mathrm{J}$ odasının batısında bulunan K odasının korunmuş bölümünün ölçüsü 16,80 × 15 × 90 metredir ve J odasına bu odadan ulaşılmaktadır. Bu iki odanın birbiri ile olan bağı kuşkusuz aynı yapıya ait iki oda olduğunun göstergesidir, ancak yapının batı bölümüne ilişkin bir duvar kalıntısı yüzeyde görülemediği için planı, kaç odalı olduğu ve işlevi noktasındaki veriler yetersiz kalmaktadır. J ve $\mathrm{K}$ odalarının güneyinde yan yana sıralanmış halde $\mathrm{L}, \mathrm{M}, \mathrm{N}$ odaları bulunmaktadır ve $\mathrm{L}$ odasının kuzey duvarı J ve $\mathrm{K}$ odaları ile or-

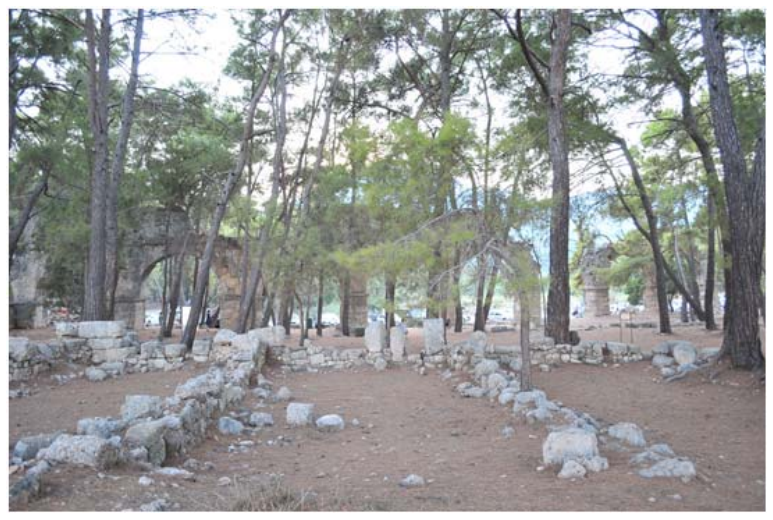

Fig. 19. Merkezi Liman L, M, N Odaları Doğudan Görünüş taktır. Girişi tespit edilemeyen L odası 13,00 x 6,00 m ölçülerindedir ve doğu-batı uzantılı dikdörtgen bir plana sahiptir. $L$ odasına paralel ve $L$ odasının güneyinde bulunan $\mathrm{M}$ odası 13,00 × 2,60 m ölçülerinde dikdörtgen planlıdır ve duvarları 1,00 m seviyesine kadar korunmuştur. Odanın 0,60 m genişliğindeki girişi, alanda bulunan benzer planlı odaların aksine batıdaki kısa kenar duvarı ortasında bulunmaktadır. M odasının güneyinde ve $M$ odası ile ortak duvarı bulunan $N$ odasının ölçüleri ise 13,00 × 4,90 metredir. Girişi tespit edilemeyen N odasının da $\mathrm{G}$ ve $\mathrm{H}$ odalarında olduğu gibi birlikte planlandıkları anlaşılmakta ancak birbirine geçiş bulunamadığı için aynı yapının odaları olup olmadığı anlaşılamamaktadır. Diğer yandan alanın planına bakıldığında J, K, L, M, N odalarının büyük bir yapı kompleksinin bölümleri olabileceği değerlendirilmekte ancak bu alanda bir kazı çalışması yapılmadan kesin bir yargıya varılamamaktadır (Fig. 1, 19).

\section{Değerlendirme}

Phaselis Merkezi (Kent) Limanı'nın boyutu, konumu, daraltılmış girişi ${ }^{15}$, kulelerle güçlendirilmiş mendirekleri ve Hellenistik Dönem kent suru ile çevrili olması nedeniyle askeri amaçlar için inşa edildiği anlaşımaktadır. Antikitede limanlar, tipolojik bakımdan intiyaca ve topografyaya göre çeşitlilik göstermektedir ${ }^{16}$. Klasik Dönem'e tarihlendirilen Korinthos, Peiraieus ile Knidos, Hellenistik Dönem'e ait Rhodos, Kos, Kantharos ve Roma Imparatorluk Dönemi'ne tarihlendirilen Traianus, Kartaca ve Leptis Magna limanları askeri özellikler taşıyan örneklerdir ${ }^{17}$. Benzer örneklerden yola çıkılarak askeri amaçlı inşa edildiği anlaşılan Merkezi Liman havzasında savaş gemilerinin kullanılmadıkları sırada sudan çıkarılarak bekletildikleri gemi barınaklarının da bu alanda bulunması beklenmektedir ${ }^{18}$. Phaselis kent sikkeleri üzerinde savaş gemilerinin betimlenmiş olması ${ }^{19}$ kentin donanmasında askeri gemiler bulunduğunun güçlü bir delili olmasına karşın limanın günümüze ulaşabilmiş bölümlerinde gemi barınağı olabilecek bir mimari yapıya rastlanılmamakla birlikte, ileriki yıllarda bu alanda yapılacak kazı çalışmaları ile bu konunun daha netlik kazanacağı kuşkusuzdur.

Phaselis Merkezi Limanı'nın tarihlendirilmesi konusunda ise kesin tarih verecek yazılı bir veri

\footnotetext{
15 Askeri limanların kulelerle güçlendirilen dar girişleri zincirlerle kapatılmaktadır. Bk. Schaw 1972, 89.

16 Aslan 2011, 24 vd.

17 Rollo 1934, 40; Shaw 1972, 89; Blackmann 1982 80; 2008, 645 vd.; Bouras 2014, 670.

18 Shaw 1972, 92; Blackman 1982, 206.

19 Tüner-Önen 2008, 57, 63, 97.
} 
ya da bir buluntunun henüz ele geçmiş olmaması nedeniyle duvar blok özellikleri ve örgü biçimi ile MÖ I. - MS I. yüzyılda yaşamış coğrafyacı Strabon'un aktarımı bu noktada tarihlendirme kriteri olarak kullanılabilmektedir. Liman mendireklerinin günümüze ulaşan kısmı ile çevresinde dağılmış blokları incelendiğinde, benzer nitelikte blok ve duvar işçiliği gösteren antik Lykia coğrafyasındaki Teimiussa, Andriake ${ }^{20}$, Myra, Sura, Gürses, Karabel, Hayıtlı'da yer alan ${ }^{21}$ Erken Hellenistik kule yapıları ${ }^{22}$ ile bosajlı ve izomomik duvarları benzeşmekte, ancak daha düzleştirilmiş bosajlı blokları, bosajların etrafında oluşturulmuş geniş ve düzgün bosaj aynası ile Erken Hellenistik bosajlı duvarlarından daha geç bir tarihten olduğuna işaret etmektedir. Kentte bu duvara benzer nitelikte MS II. yüzyıla tarihlendirilen Phaselis tiyatrosunun batı analemna duvarı bulunmakta, ancak bu duvarın bloklarında kullanılan bosajların çok daha düz ve alçak işlenmiş olması, bosaj aynalarının ise çok daha geniş tutulmuş olması, bu duvarın liman mendireğindeki duvarlardan daha geç bir dönemden olduğu şeklinde yorumlanabilmektedir. Dolayısıyla gerek bu duvar iş̧̧iliklerinin karşılaştırılması gerekse Strabon'un aktarımından yola çıkılarak Phaselis Merkezi Limanı Geç Hellenistik - Erken Roma İmparatorluk Dönemleri arasına tarihlendirilebilmektedir. Özellikle MÖ I. yüzyılda bölgedeki korsanlık faaliyetlerinin artması ${ }^{23} \mathrm{da}$ Phaselis'in denizden gelebilecek tehditlere yönelik bir önlem olarak askeri limana ihtiyaç duymuş olabileceği düşüncesi, limanın tarihlendirilmesi noktasında kayda değer diğer bir veridir.

Merkezi Liman'a ilişkin diğer bir olgu ise bu alanda yer alan rıhtım ve diğer işlik ya da depo alanlarının işlevi ve tarihlendirilmesidir. Limanın gerisinde yer alan ve rıhtım işlevi gören alanın duvar işçiliği, duvar örgü tekniği ve kullanılan malzemesi limanın mendireklerinden oldukça farklılık göstermektedir. Öyle ki liman mendireklerinde kullanılan bloklar bosajlı ve büyük boyutlu bloklar olmasının yanı sıra rıhtım alanında olduğu gibi bağlayıcı malzeme olarak harç kullanılmamıştır. Söz konusu rıhtım ve gerisindeki depo ya da dükkân benzeri mimari yapılar, limanın ilk inşasından daha geç bir tarihte limanın tekrar organize edilmesi ile rıhtıma yanaşan gemilerin kargolarını boşalttıkları ve Phaselis'ten ihraç edilecek malların gemilere yüklendiği işlevsel bir ticaret alanı olduğunu göstermektedir. Benzer ticari amaçıı limanlarda da bu alanda dükkânlar, depolar, gümrük binaları ve sarnıçlar gibi mimari yapılar bulunmaktadır ${ }^{24}$. Ancak askeri amaçı limanlarda bu olgu ile karşılaşılmamakta ve askeri liman özellikleri gösteren Phaselis Merkezi Liman alanında da sözü edilen bu yapılar ile yukarıda detaylarına yer verdiğimiz diğer depo-işlik ve atölyelerin limanın ilk inşasında amaca yönelik olarak bulunmaması gereken yapılardır. Dolayısıyla bu alanların limanın ilk inşasından sonraki bir dönemde kullanıma girdikleri düşünülmektedir.

Phaselis Merkezi Liman mendirekleri için araştırılması gereken diğer bir konu ise ne zaman ve neden yıkıldıkları sorusudur. Limanın mendirekleri ve neredeyse tamamı batı yönde yıkılmış olan blokları incelendiğinde güçlü bir dalga ile tek seferde aynı yöne yıkılııları anlaşılmaktadır (Fig. 1). Bölgede liman mendireklerine böylesine yıkıcı etki yapabilecek güçte bilinen deprem ve tsunamilere bakıldığında MS 68 yılında Mısır kökenli bir tsunaminin özellikle Orta Lykia'da etkili olduğunu MS II. yüzyıl yazarı Cassius Dio ${ }^{25}$ aktarmaktadır $^{26}$. Phaselis Merkezi Liman mendirekleri

20 Marksteiner 1997, taf. 41 abb. 115, taf. 66 abb. 184, 185.

21 Konecny 1997, taf. 8 abb. 23, taf.13 abb. 35, taf.18 abb. 53, taf.25 abb. 73, taf. 30 abb. 91, taf. 37 abb. 114.

22 Konecny 1997, 81 vd.

23 Arslan 2003, 91 vd.; Tüner-Önen 2012b, 481.

24 Shaw 1972, 91; Blackman 1982, 204; 2008, 653; Casson 2002, 143.

25 Cass. Dio LXIII. 26. 5.

26 Şahin 2013, 127 dn. 115. 
bu dönemde tsunamiye maruz kalarak yıkılmış olsa bile MS II. yüzyılda kenti ziyaret eden Roma Imparatoru Hadrianus'un ${ }^{27}$ gelişinden önce onarılmış olması gerekirdi. Bölgede yıkıcı bir etki yaptığı bilinen MS 141 depremi sonrasında kentte Opramoas'ın onarım için yardımları nedeniyle onurlandırma yazıtı bulunmakta ${ }^{28}$, diğer yandan Roma İmparatoru Caracalla'nın Küçük Asya'daki büyük imar faaliyetleri bilinmektedir. Ancak mendireklerin günümüz durumu incelendiğinde böylesine büyük çaplı bir onarımın izlerine rastlanmamaktadır. Bölgede bilinen diğer büyük tsunami ise Leonardo Da Vinci'nin aktardığı 1459 Antalya depremidir ${ }^{29}$. Söz konusu depremin Phaselis Merkezi Liman mendireklerini yıkabilecek derecede etkili bir tsunamiye neden olabileceği anlaşılmaktadır. Phaselis Merkezi Liman mendireklerini yıkabilecek derecede etkili diğer bir tsunami ise, Marsilya Ticaret Odası kayıtlarında 6-20 Mayıs 1743 tarihlerinde gerçekleşmiş olan ve Antalya'nın batısında yer alan Sıçan Adası'nın bulunduğu alanda dağların tamamen suya gömüldüğü rapor edilmiştir ${ }^{30}$. Merkezi Liman için, 1811-1812 yıllarında kenti ziyaret eden Beaufort'un anlatımına bakılacak olursa, taş iş̧̧iliğinin halen görülebildiği; ancak ayakta olmayan bir limandan söz ettiği anlaşılmaktadır ${ }^{31}$. Dolayısıyla kuşkusuz bir tsunami nedeniyle tek seferde yıkıldığı öne sürülen mendireklerin MS 14. yüzyıl ile 18. yüzyıl arasında bir tarihte yıkılmış olması gerektiği kanısı uyanmaktadır. İlk inşasından sonra kayıtlara geçen birçok fırtına ve tsunamiye mukavemet gösterdiği anlaşılan liman MS VII. ve VIII. yüzyılda da Doğu Roma Imparatorluğu'nun ana limanlarından biri olmuştur. Phaselis Merkezi Liman mendireklerinin bu tarihler sonrasında neden tsunamiye karşı koyamadığının nedenlerinden biri de muhtemelen MS 861-904 yılları arasında Arap akınları ile yıkılan Attaleia kent surlarının onarımında kullanılmak üzere Phaselis'ten MS 912-916 yılları arasında Attaleia'ya blok taşındığı ${ }^{32}$ sırada mendireğe ait blokların da sökülmüş ve bütünlüğünün bozularak daha dayanıksız bir duruma geçirilmiş olmasıdır.

\footnotetext{
27 Tüner-Önen 2013, 93 vd.

28 Tüner-Önen 2012b, 483.

Dipova - Cangir 2011, 8.

Dipova - Cangir 2011, 8.

Beaufort 1818, 59.

32 Akan 1996, 71; Tüner-Önen 2012b, 481.
} 


\section{BíBLIYOGRAFYA}

\section{Antik Kaynaklar}

Cass. Dio

Strab.

\section{Modern Literatür}

$A A$

Akan 1996

Arslan - Tüner Önen 2013

Arslan 2003

Arslan et al. 2013

Aslan - Baybo 2015

Aslan 2011

Aslan 2014

Bayburtluoğlu 1983

Bean 1968

Beaufort 1818

$B J b$

Bjorn 2011

Blackman 1973

Blackmann 1982

Blackmann 2008

Bouras 2014

Casson 2002

Dipova - Cangir 2011

Doksanaltı - Aslan 2013
(= Cassius Dio, Rhomaika)

Kullanılan Metin ve Çeviri: Cassius Dio, Roman History, vols. I-IX. Trans. E. Cary - H. B. Foster. London 1914-1927 (The Loeb Classical Library).

(= Strabon, Geographika)

Kullanılan Metin ve Çeviri: Strabo, The Geography of Strabo. Trans. H. L. Jones. London - New York 1961 (The Loeb Classical Library).

\section{Archäologischer Anzeiger.}

T. Akan, Archaeological Heritage Management For Conservation and Development Case Study: Phaselis. Yayımlanmamış Yüksek Lisans Tezi, Orta Doğu Teknik Üniversitesi. Ankara 1996.

M. Arslan - N. Tüner Önen, "2012 Yılı Phaselis Antik Kenti ve Teritoryumu Yüzey Araştırması”. AST 31/1 (2013) 78-89.

M. Arslan, "i.Ö. 188 Yılından I.Ö. 67 yılına Kadar Lykia, Pamphylia ve Kilikia Trakheia Sahillerindeki Korsanlık Faaliyetleri: Nedenleri ve Sonuçları". Adalya VI (2003) 91-118.

M. Arslan, K. Demirtaş - N. Tüner Önen, "Phaselis ve Teritoryumu Yüzey Araştırması 2012". Anmed 11 (2013) 224-229.

E. Aslan - S. Baybo, "Phaselis Kent Limanları ve Sualtı Araştırmalarının Ön Değerlendirmesi". Phaselis I (2015) 1-17.

E. Aslan, Kekova Bölgesi Limanları. Yayınlanmamış Doktora Tezi, Selçuk Üniversitesi. Konya 2011.

E. Aslan, "Bithynia Bölgesi Kalpe Limanı (Port of Kalpe in the Bithynian Region)". Olba XXII (2014) 129-154.

C. Bayburtluoğlu, "1982 Phaselis Kazısı Raporu”. KST V (1983) 181-189.

G. E. Bean, Turkey's Southern Shore. London 1968.

F. Beaufort, Karamania or a Brief Description of the South Coast of Asia Minor and of the Remains of Antiquity. London 1818.

Bonner Jahrbücher des Rheinischen Landesmuseums in Bonn und des Vereins von Altertumsfreunden im Rheinlande. Bonn.

L. Bjorn, The Ancient Harbours of the Piraeus. Volume I. 1: The Zea Shipsheds and Slipways - Architecture and Topography. Athens 2011.

D. J. Blackman, "The Harbours of Phaselis". IJNA 2/2 (1973) 355-364.

D. J. Blackman, "Ancient Harbours in the Mediterranean". IJNA 11/3 (1982) 185-221.

D. J. Blackman, "Sea Transport, Part 2: Harbors". Ed. J. P. Oleson, The Oxford Handbook Engineering and Technology in The Calassical World. Oxford (2008) 638-670.

C. Bouras, "On the Urbanism of Roman Harbours: the Evolution of Space Organization in Harbours of the Aegean Sea". Byzas XIX/2 (2014) 669- 682.

L. Casson, Antik Çağda Denizcilik ve Gemiler. Çev. G. Ergin. İstanbul 2002.

N. Dipova - B. Cangir, "Antalya İli Yerleşim Alanının Depremselliğinin Araştırılması". Jeoloji Mühendisliği Dergisi 35/2 (2011) 93-114.

E. M. Doksanaltı - E. Aslan, "Karadeniz'de Antik Bir Ada Yerleşimi: AretiasKhalkeritis Adası". Ed. B. Söğüt, Stratonikeia'dan Lagina'ya - Ahmet Adil Tırpan Armağanı - From Stratonikeia to Lagina - Festschrift in Honour of Ahmet Adil Tirpan. İstanbul (2013) 219-240. 
Gerkan 1959

Hadjidaki - Stefanakis 2004

IJNA

Knoblauch 1969

Knoblauch 1972

Konecny 1997

Lehmann-Hartleben 1923

Marksteiner 1997

Mengarelli 1900

Rollo 1934

Schäfer et al. 1981

Schläger - Schäfer 1971

Shaw 1972

Stark 1956

Şahin 2013

Teodoulou - Memos 2007

Testaguzza 1964

Testaguzza 1970

Tüner-Önen 2008

Tüner-Önen 2012a

Tüner-Önen 2012b

Tüner-Önen 2013

Williams 1976
A. von Gerkan, Von Antike Architektur und Topographie: Gesammelte Aufsätze. Ed. E. Boehringer. Stuttgart 1959.

E. Hadjidaki - M. Stefanakis, "Secrets of Phalasarna. Critiko Panorama". Minoa Editions (2004) 101-135.

The International Journal of Nautical Archaeology and Underwater Exploration. Portsmouth.

P. Knoblauch, "Neuere Untersuchungen an den Häfen von Ägina”. BJb 169 (1969) 104-116.

P. Knoblauch, "Die Hafenanlagen der Stadt Ägina". Adelt 27A (1972) 5085.

A. Konecny, Hellenistische Turmgehöfte in Zentral-und Ostlykien, Vol. 2. Wien 1997.

K. Lehmann-Hartleben, Die Antiken Hafenanlagen des Mittelmeer. Aalen 1963.

T. Marksteiner, Die befestigte Siedlung von Limyra: Studien zur vorrömischen Wehrarchitektur und Siedlungsentwicklung in Lykien unter besonderer Berücksichtigung der klassischen Periode, Vol. 1. Wien 1997.

R. Mengarelli, "Terracina. Pietro di ormeggio, scolpita, rinvenuta presso il molo dell'antico porto". Notizie degli Scavi di Antichita (1900) 635-638.

W. Rollo, "Ostia." Greece and Rome 4/10 (1934) 40-53.

J. Schäfer, H. Schläger, D. J. Blackman, H. Bremer, J. Christern - P. Knoblauch, Phaselis, Beiträge zur Topographie und Geschichte der Stadt und ihrer Häfen. Tübingen 1981.

H. Schläger - J. Schäfer, "Phaselis Zur Topographie Der Stadt und Des Hafengebietes". AA 86 (1971) 542-561.

W. J. Shaw, "Greek and Roman Harbours Works". Ed. G. F. Bass, A History of Seafaring Based on Underwater Archaeology. London (1972) 87-102.

F. Stark, The Lycian Shore. London 1956.

S. Şahin, Stadiasmus Patarensis: Likya Eyaleti Roma Yolları. Ed. S. Şahin M. Adak. İstanbul 2013.

T. Theodoulou - C. Memos, "A Voyage to Ancient Greek Harbours on Board Limenoscope". Water Science \& Technology: Water Supply 7/1 (2007) 253-260.

O. Testaguzza, "The Port of Rome". Archaeology 17/3 (1964) 173-179.

O. Testaguzza, Portus: illustrazione dei Porti di Claudio e Traiano e della città di Porto a Fiumicino. Julia 1970.

N. Tüner-Önen, Phaselis Antik Kenti ve Teritoryumu. Yayımlanmamış Doktora Tezi, Akdeniz Üniversitesi. Antalya 2008.

N. Tüner-Önen, "Ideas Concerning the Historical Identity and the Connections of the City of Phaselis an Eastern Mediterranean Port". MJH II/I (2012) 205-212.

N. Tüner-Önen, "Yazıtlar Işığında Phaselis". Eds. K. Dörtlük, T. Kahya, R. B. Seyhan - T. Ertekin, Uluslararası Genç Bilimciler Buluşması I: Anadolu Akdenizi Sempozyum Bildirileri 4-7 Kasım 2009. İstanbul (2012) 479-488.

N. Tüner-Önen, "Hadrians Reisen im östlichen Mittelmeer anhand neuer Inschriften aus Phaselis". Adalya XVI (2013) 93-106.

P. F. C. Williams, "Roman Harbours". IJNA 5/1 (1976) 73-79. 